\title{
The Role of Self-efficacy in Adapation Regarding Parental and Child Resilience - A Longitudinal Study on the Two Waves of Covid 19
}

\section{Andrea Kövesdi*, Gábor Csikós, Krisztina Törő, Éva Hadházi, Szabolcs Takács, Sándor Rózsa and Rita F Földi}

Károli Gáspár Református University, Institute of Psychology and Resilient

Development Positive Research Group, Hungary

*Corresponding Author: Andrea Kövesdi, Károli Gáspár Református University, Institute of Psychology and Resilient Development Positive Research Group,

Hungary
Received: January 22, 2021

Published: February 27, 2021

(C) All rights are reserved by Andrea Kövesdi., et al.

\begin{abstract}
The COVID-19 epidemic also affects families in terms of material, work and relationships, and daily habits. The past 9 months are a lot of time during the extraordinary and stressful period, and its effects will be felt in the long run. Increased anxiety (e.g., double incidence in Canada, [15]) may change basic habits and long-term effects cannot be predicted. Presumably, individual- and familylevel adaptation patterns, flexibility, or rigidity determine long-term changes. The study addresses the effects on family balance during COVID 19, such as perceived stress, health anxiety, and addresses psychological factors that support flexible adaptation during a pandemic period. For example, in the first wave, activity and movement showed a positive association with resilience [1,30] as an option for self-efficient behavior. Analysis of the first and second samples of our longitudinal study shows similar results where selfefficacy is a protective factor against the stress that occurs in a pandemic. Resilience is also a protective factor for both parents and children against the stress caused by the effects of the epidemic. Child welfare declined by the end of 2020. We recommend finding and practicing forms of self-effective behavior as a defense to reduce the stress and anxiety associated with a pandemic.
\end{abstract}

Keywords: Parent and Child; Resilience; Self-efficacy; Pandemic; Burdens; Resources

\section{Introduction}

Due to the COVID 19 epidemic in Hungary, restrictions have been in place since March 2020 with a milder summer period. In the spring of 2020, our research group started collecting data among the Hungarian population. Data were collected by parentchild pair filling. Based on the spring results, parents have higher resilience values compared to their children, but the values are in an average zone. The perceived stress value of the girls was the highest in the whole sample. Self-efficacy is a protective factor in terms of resilience, reducing the resilience-reducing effect of health anxiety and percvieved stress. Also, parental self-efficacy is a protective factor against the resilience-reducing effect of perceived stress in children [33].

Different statements can be heard about the psychic aspects of the COVID 19 period, where crisis and trauma are mentioned by professionals. It reveals a lot about uncertainty when the name of a given situation is not clear either. The concept of crisis can be partially adapted to the period. In the first 6-8 weeks, the concept of a crisis was fulfilled, but in the six months since then, we have 
to reckon with the current viral infection and its other effects in everyday life in the meantime.

\section{Crisis or trauma}

According to Erikson's [17] conception of crisis, we speak of a developmental crisis - supporting development - and an accidental crisis [6] that develops during an unexpected, sudden onset of impact. Jacobson's [26] crisis matrix includes the simultaneous occurrence of two phenomena. The use of the crisis matrix is valid for the studied adolescents, which can last from a few months to years. In a crisis, we mobilize extreme energies and all the attention of the person is focused on finding a solution, as the challenge cannot be overcome with the usual problem-solving tools [21,43]. In the long run, this extreme functioning cannot be maintained by the person leading to fatigue and then ultimately leading to burnout [21]. Caplan [6] emphasizes the role of the support system in terms of the outcome of a crisis, which ends with success, personal enrichment, or injury. The peculiarity of the crisis state is that it divides the life story, is a milestone in a person's life and takes place in 6-8 weeks [21]. Crises in human life were tabulated by Holmes [23] and scored on severity. However, a pandemic has not been classified in this table, although it has occurred in the past. A pandemic is not a normal part of human life in Holmes' conception, which we can fight badly or badly. As we can see, we cannot accurately describe the events of the COVID-19 period as a crisis, as it is not one of the normal crises with human life cycles and lasts for more than 6-8 weeks, people face almost every day in almost all parts of the world. vulnerability and helplessness with severe and sudden losses.

Half a year after the crisis, the traumatic impact of the viral situation is also to be expected. Turk [47] describes trauma as an extreme violent effect that leaves indelible marks even after healing, both physically and mentally. Traumatic experience when a person is faced with an external condition that destroys his life [48]. The victim experiences helplessness and isolation, rationally uncontrollable in the face of threatening force [18]. The magnitude of a traumatic event is so great that it is not possible to predict it even if the event can be expected to occur [38]. In addition to the one-time traumatic event, Kris [34] mentions stress trauma, which is a traumatic effect lasting for a longer period of time. Based on the conceptual reviews, we are presumably experiencing a traumatizing period worldwide, regardless of gender, skin color, existential affiliation and education, a collective experience. Formulating this is perhaps the first step in mitigating the psychological effect, which is partly our goal by communicating our research. We consider it important to monitor changes the longitudinal section during this extraordinary period, where we believe that it is worthwhile to seek to minimize the traumatic effect by strengthening protective factors. After the first recording (month 04/04/2020), we were able to keep $1 / 6$ of the sample indoors for the second sampling period (month 12/11/2020).

\section{Vulnerable and protective factors in the COVID-19 period}

It is a known fact that in an emergency, crisis, traumatic stress, we experience high stress, followed by post-traumatic stress reactions, depression and severe anxiety. In such a situation, the personal loss is followed by a complex process of mourning [13]. However, we respond differently in an emergency, same individuals can adequately mobilize resources in a dangerous situation, allowing mental health to be maintained [3]. The complexity of the COVID 19 epidemic complicates and undermines individuals 'natural elastic responses [20]. The authors consider maintaining and strengthening resources as an appropriate treatment for the situation [19]. "Stress is the acid pepper of life" (Selye, 1976, pp.:79.)

According to János Selye [42], every unknown, unexpected life situation triggers a non-specific response, a vegetative stress response. During a pandemic, stress has clearly a long lasting effect. Stress, coping strategies, and psychological adjustment are closely related $[19,22]$. High stress levels are especially dangerous when combined with maladaptive coping. In adolescents Maladaptive coping strategies may also be associated with depression, anxiety disorders, and harmful substance use [25,35].

Children whose parents reported high levels of stress showed more externalization problems and developed poorer emotion regulation [11]. Adolescent development is accompanied by an alternation of sensitive periods, characterized by psychological problems and emotional difficulties in addition to physical changes, The number of depressive and psychosomatic illnesses is increasing [40].

The effect of stress on the lives of parents and their children during COVID 19

The coronavirus epidemic has been accompanied by a change in the daily routine of parents and their children, which imposes 
serious additional burdens on families [10]. Adolescents are particularly affected by the changes resulting from the epidemic. Anxiety and depressive symptoms have been identified in Chinese adolescents as in adults [51]. An increasing trend in the presence of symptoms was found in adolescent adolescents of higher grades. They concluded that quarantine best tolerates graduate students $[16,51]$. During the quarantine period, children and adolescents experience fear, insecurity, isolation, separation from friends, and dropping out of school life. In a study of children aged 6-18 years in China, attachment, inattention, and irritability were found to be the most severe psychiatric symptoms [28].

In addition to the threatening aspects of the stress effect, the presence of protective factors influences responses to a stressful life event. The person's protective factors were identified the ability to control, learned ingenuity, hard right personality, selfawareness, self-efficacy, resilience, sense of coherence, optimism, constructive thinking, emotional intelligence (EQ), and spiritual intelligence (SQ). Among the mentioned protective factors, the focus of our study is resilience and, in this context, self-efficacy.

\section{Resilience}

The phenomenon of resilience is described by the authors in several definitions, as it is a multifaceted complex phenomenon. It was previously considered a special ability, but more recently it appears more like an adaptation that exists in most people. Without wishing to be exhaustive, it is mentioned with definitions relevant to the study. According to Békési, "resilience is resilience, which is the reactive ability of a system - be it individual, ecosystem, kind of material - to successfully adapt to strong renewable or even diverse external influences" [32]. Among the phenomena of psychology [37], considers resilience to be a personality trait that is closely related to the ability to adapt, and the person is characterized by internal control, empathy, and self-effective behavior. Chicetti and Cohen [7] further point out that the resilient person responds with competent functioning despite external and/or internal influences, even after prolonged or severe trauma. The authors consider it likely that competent functioning maintained under stress may indicate resilience [39].

Under the influence of the stressor, we react in a resilient or non-resilient way by the cooperation of risk factors and protective factors, one of the manifestations of which is the nature of coping [50]. Resilient individuals are able to store and positively use stress-induced stress. Resilient operation is a complex adaptive ability that is constantly changing depending on age, life situation, and external factors.

Examining the period of epidemics, it has been shown that most people are resilient, but how much is influenced by the interplay of several factors, including individual differences, the family web, and the supportive community around the individual [44].

\section{Self-efficacy in parent-child interaction}

Self-efficacy is a personality potential that is a belief in ourselves and the certainty that we can able to achieve our goals. Self-efficacy is a significant factor in coping with stress [2]. Self-effective individuals tend to see stressful situations as a challenge [12]. Parental self-efficacy in the way they handle their child-related responsibilities affects a child's ability to adapt [29]. A properly self-effective parent who employs a positive parenting and parenting strategy promotes his or her child's adaptation and maturation of emotion regulation [45].

In the spring period of COVID-19, children with special needs and their mothers were studied by Turkish researchers, and their results show that maternal self-efficacy and resilience go hand in hand [14].

\section{Test objective}

Our study objective is to compare the perceived stress responses of parents and their children and to measure the change in resilience during the first (spring 2020) and second wave (autumn/ winter 2020) of a Hungarian sample in the COVID-19 period. In formulating our research objective, we relied on our practical experience and the international literature.

We state that the resilience value of parents is higher than that of children at both the first and second measurements. Resilience shows a positive correlation with self-efficacy and a negative correlation with health anxiety and perceived stress in both measurement periods. Children experience less stress than their parents in the second wave and their health anxiety decreases. Perceived stress and health anxiety reduce resilience throughout the period. Last but not least, parental self-efficacy influences child resilience where there is no difference between spring and winter measurement data. 


\section{Presentation and method of the test sample}

According to the study design, parents and their children completed the questionnaire package. Random sampling was performed by the snowball method on an online interface. The sample was overrepresented by women versus men, and the children's sample was balanced. The analysis of the first sample was performed with 648 people (parent and child), in the second sample the data of 44 respondents (88 people) (parent and child) were analyzed. 50 fillings (100 people) were received, however, 6 fillers (12 people/parent-child) were excluded from the analysis for various reasons. $1 / 6$ of the sample could be included in the second sample. We sent reminders to families on a weekly basis for 4 weeks.

The exclusion criteria were double completion (4 pairs of respondents), 1 person had no partner, 28 people did not agree to the survey (although they undertook the second sampling in the spring), 28 respondents misunderstood the call, 258 partner pairs agreed but did not complete it. the questionnaire. After data purification, the data of 44 filling pairs (88 persons) from the second sample were analyzed.

\begin{tabular}{|l|c|c|c|}
\hline & Age $/ \mathbf{M}$ & SD & N = 648 \\
\hline Fathers & 47.16 & 4.282 & 32 \\
\hline Mothers & 43.70 & 5.047 & 310 \\
\hline Boys & 14.07 & 2.211 & 134 \\
\hline Girls & 14.33 & 2.213 & 208 \\
\hline & Age/M & SD & $\mathbf{N}=\mathbf{8 8}$ \\
\hline Fathers & 45.75 & 5.737 & 4 \\
\hline Mothers & 45.20 & 4.832 & 40 \\
\hline Boys & 14.33 & 1.983 & 21 \\
\hline Girls & 14.22 & 2.022 & 23 \\
\hline
\end{tabular}

Table 1: Sample characteristics.

Psychometric devices included in the study;

- CD-RISK 10-item resilience questionnaire [9],

- $\quad$ Perceived Stress Scale $[8,46]$,

- Bandura self-efficacy questionnaire [2],

- $\quad$ Short Health Anxiety Inventory [31,41].

\section{Results}

The reliability of psychomeric devices is similarly adequate to the results of the spring analysis. The reliability index of health anxiety and child perception stress questionnaires is the lowest (Cronbach alphas between 0.661 and 0.922). In terms of demographics (eg place of residence, education, financial situation, etc.) there is no significant difference between those who fill in the second wave and those who fill in the first wave, except for education, the participants in the second wave have a higher education (Mann-Whitney $\mathrm{U}=5045.5 \mathrm{Z}=2.640 \mathrm{p}=.008$ ). Among those completing the second round, the proportion of university graduates is higher (36.4\% vs $20.9 \%$ ) and the proportion of vocational school graduates is lower (22.7\% vs $34.5 \%$ ).

\section{Analysis of children's data}

The spring sample was divided into two groups in terms of whether or not the questionnaire was completed in the winter. Correlation analysis compared to the results of the first sampling gave similar results during the analysis of the second period.

Looking at the whole sample, neither significant values of protective factors (resilience, self-efficacy, well-being) nor vulnerabilities (perceptual stress, health anxiety) were found, with one exception, children's health anxiety was significantly reduced, $t(43)=$ $2,283 \mathrm{p}=.027$.

The advantage of the repeated measurement arrangement is that spring and autumn measurements can not only be compared at the sample level, but also the change within individuals can be calculated and interpreted. Subtracting the spring ones from the autumn values of the individuals, we get the direction and the extent of the change in their psychological state during the summer period. We examined the extent to which the spring mental state of the respondents was affected by changes in their mental state during the summer.

For the whole sample, the value of resilience decreases at the trend level, however, individuals who measured a lower value in the spring have a smaller rate of decrease in the second wave. Those with higher resilience values in the spring have a more significant decrease in the winter period. The correlation between the resilience measured in the first survey and the change in resilience for parents $r=-.287 \mathrm{p}=.030$; for children $r=-.389 \mathrm{p}=.004$.

The child sample is gender balanced, so the gender effect can be examined for children as well. We examine quality of life, resilience, and well-being in terms of children's gender. In the context 
of quality of life (Figure 1), the quality of life of boys did not change, that of girls decreased. In terms of resilience (Figure 2), based on the gender distribution, we also see that the resilience value of boys did not change, while a trend-level decrease in the resilience of girls can be seen. In terms of well-being, we see a similar trend compared to the previous one (Figure 3).

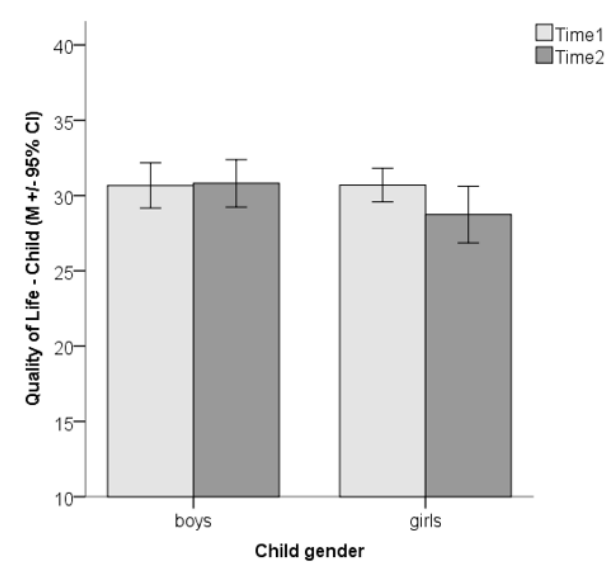

Figures 1: Non-quality of life, non-resilience.

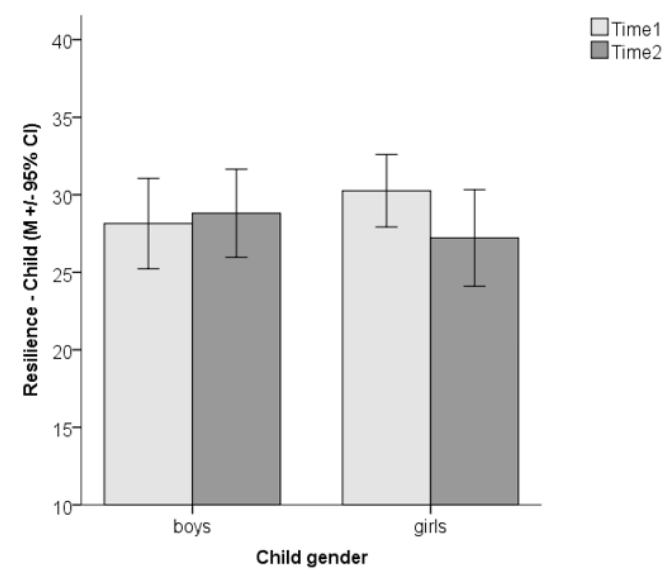

Figures 2: Non-quality of life, non-resilience.

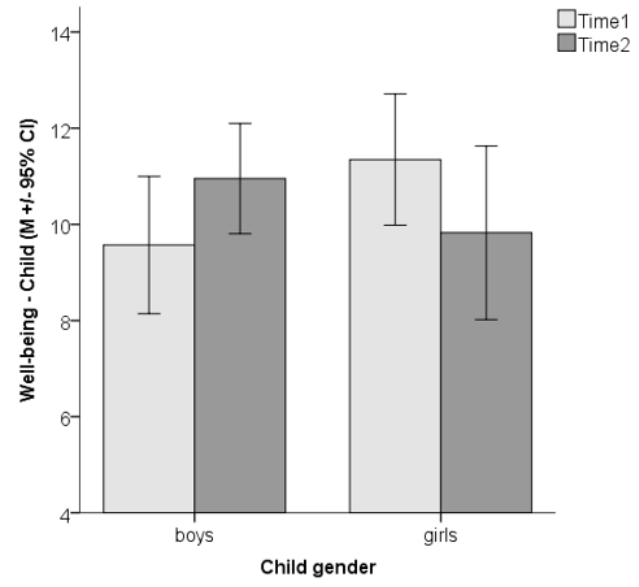

Figures 3: Non-quality of life, non-resilience.

In parents, gender testing was not possible due to unequal sex ratios.

Changes in the condition of parents and their children over time

The rate of decrease is greater in individuals who gave higher values than the spring measurement. Individuals who had high stress values in the spring remained high, however, those who had low values increased in both the parental and child sample. Children's health anxiety has decreased, in detail, individuals who have not previously had health anxiety are still not anxious, and those who are anxious about their health are no longer so anxious. So children's fears about health are "tired," their attention is distracted by something else.

Parental sample analysis

The quality of parents 'well-being in the spring affects their winter status. Those who had below-average well-being in the spring did not show a further decrease during the pandemic period, but those who completed above-average values showed a significant decrease $(r=-.559 \mathrm{p}<.001)$. Spring well-being can also be related to changes in perceived stress, $r=.380 \mathrm{p}=.005$. For those with low well-being in the spring, high stress was already observed in the spring. For those with high levels of well-being in the spring, stress 
levels were still low in the spring, however, we see that their stress levels also increased by the winter period (Figure 4).

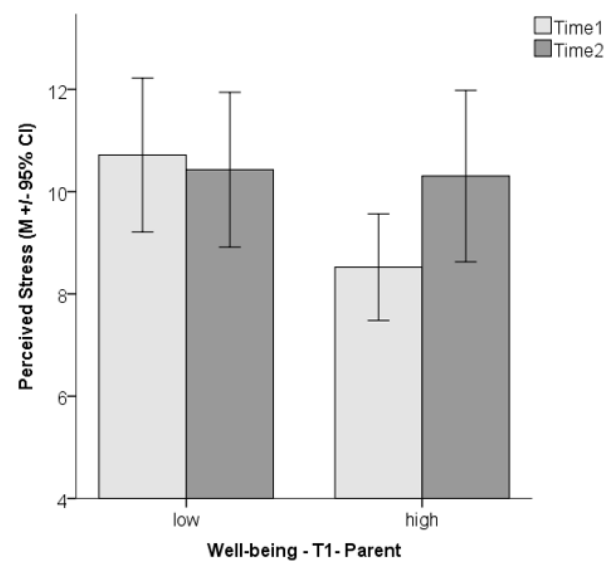

Figure 4: Change in parental well-being and perceived stress.

Parents who had a lower quality of life in the spring had lower self-efficacy. Also, lower parental self-efficacy is associated with lower pediatric resilience (Figure 5). The correlation coefficients are added to: SZ-Self-SZ-Life Change: $\mathrm{r}=.261 \mathrm{p}=.043$; SZ-EnhatGY-Resolved: $r=.278 \mathrm{p}=.034$.

\section{Correlation test as a function of time}

The results of the spring and winter study are similar, the correlations are stronger in the longitudinal section than in the crosssectional analysis, the direction of the correlations is the same. The interactions shown indicate the reliability of the measuring instruments.

\section{Mediation studies}

The results of the spring mediation study are shown in figure 6. The winter mediation analysis (Figure 7) confirmed the indirect negative effect of perceived stress on resilience, but did not confirm the direct effect of health anxiety on resilience.

\section{Discussion}

Overall, analysis of the first and second samples yielded similar results, except for children's health anxiety, which decreased.
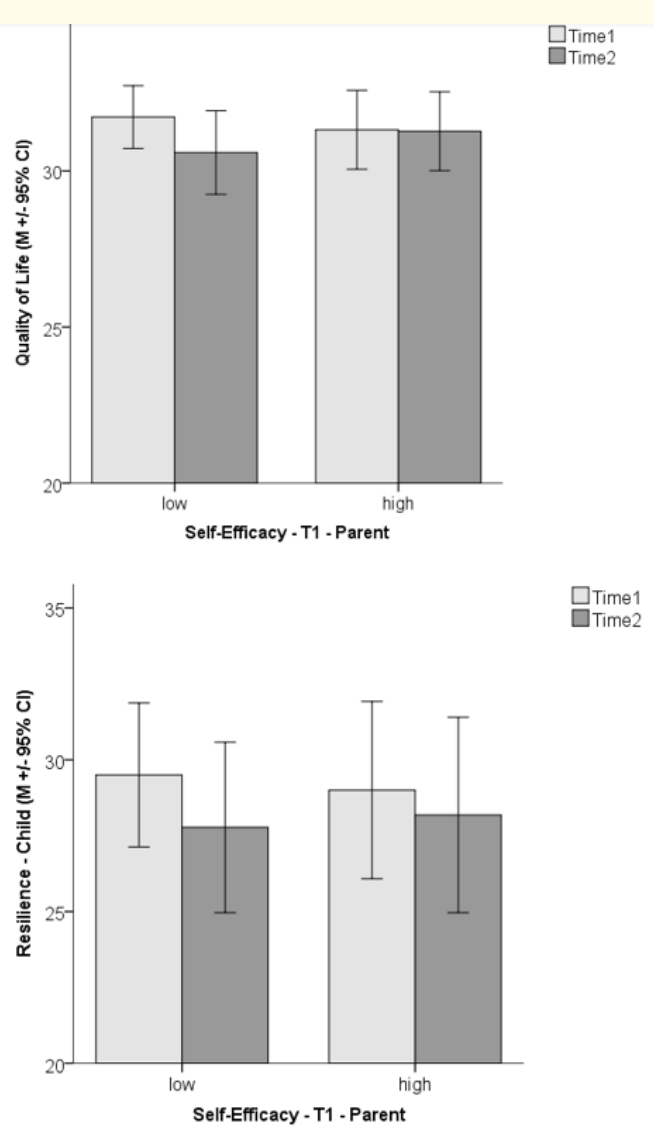

Figure 5: Relationship between parental self-efficacy-quality of life and child resilience.

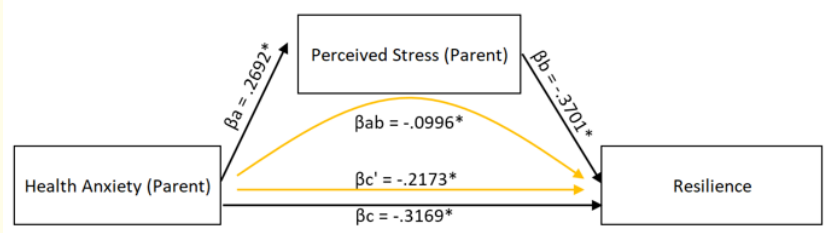

Figure 6: Health anxiety (patent) - perceived stress (parent) - resilience mediating effect [33]. 


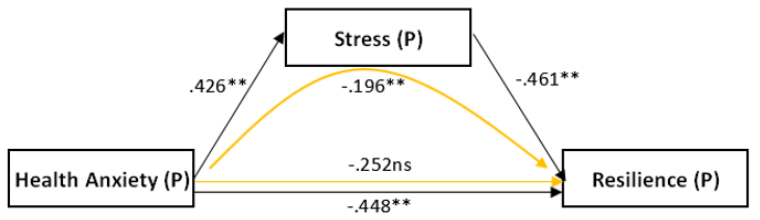

Figure 7: Winter mediation study.

\begin{tabular}{|l|c|c|c|c|c|c|c|}
\hline $\mathbf{X}$ & $\mathbf{Y}$ & Path & beta & SE & $\mathbf{p}$ & LLCI & ULCI \\
\hline HA & R & c (total) & $-0,448^{* *}$ & 0,138 & 0,002 & $-0,727$ & $-0,17$ \\
\hline HA & PS & a & $0,426^{* *}$ & 0,140 & 0,004 & 0,145 & 0,708 \\
\hline HA & R & $\begin{array}{c}\text { c' }^{\prime} \text { di- } \\
\text { rect) }\end{array}$ & $-0,252 \mathrm{~ns}$ & 0,137 & 0,072 & $-0,528$ & 0,024 \\
\hline PS & R & b & $-0,461^{* *}$ & 0,137 & 0,002 & $-0,736$ & $-0,185$ \\
\hline $\begin{array}{l}\text { HA to R } \\
\text { through S }\end{array}$ & $\begin{array}{c}\text { ab (indi- } \\
\text { rect) }\end{array}$ & $-0,196^{* *}$ & 0,096 & - & $-0,416$ & $-0,046$ \\
\hline \\
HA - Health anxiety; PS - Perceived stress; R - Resilience; \\
ns - nonsignificant; ${ }^{*} \mathrm{p}<.05 ; * * \mathrm{p}<.01$ \\
\hline
\end{tabular}

Table 2

Even children who have done so before are not worried about their health. Children's fears and anxieties about health were most likely translated into a lack of friends and "old life," which frustrates them. Jiao., et al. [28] found that during the quarantine period, children and adolescents experience fear, insecurity, isolation, separation from their friends, and dropping out of school life.

Comparing the spring and winter mental state of the infants, the value of resilience decreased, especially in the case of persons with a high resilience value in the spring. Parents 'own spring well-being affects their winter condition, for whom they reported high wellbeing in the spring, with it declining the most for the winter period. Decreases in the two protective factors, resilience and well-being, may indicate fatigue.

Fatigue is supported by the fact that during this period, the level of perceived stress increased in the overall sample, most notably in individuals who experienced less stress in the spring. Perceived stress and health anxiety show a negative correlation with resil- ience during the study period. Fatigue leads a long way, however, the myriad uncertainties that arise in a pandemic situation (the sometimes untraceable logic of restrictions, lack of information and misinformation about vaccination) and the presence of a constant emergency support psychiatric fatigue.

The present research is novel in terms of resilience, as previous studies have primarily examined stressful situations in terms of resilience where multiple stress effects were present but for a limited time and where the stressed person's environment did not experience the same stress effect as the subject. In such cases, social support, solution options, and help were available within a reasonable distance $[37,49]$. All members of the current pattern and their environment experience their daily lives with similar, prolonged stress effects, so that the temporal dimension is unpredictable even today. In order to counteract the traumatic experience, resources (eg rest, self-efficacy, sports/activity, hobbies, joyful relationships) need special care and expansion of experiences and abilities as a possible means of defense. Fiorillo and Gorwood [20] writes with similar thoughts about the complexity of the COVID 19 epidemic, which complicates and undermines individuals 'natural elastic responses. Other authors also consider maintaining and strengthening resources to be an appropriate treatment in a pandemic situation [24].

A gender-interesting distribution can be observed in the sample of children. Boy infants show no change in quality of life, resilience, and well-being between the two study periods, whereas there was a decrease in all three dimensions in the girls group. The result is striking in light of the spring results, where the stress level of the girls exceeded that of the boys, but there was no difference in resilience between the two groups [33]. The girls 'resources for the winter are significantly less, making them more vulnerable to the negative psychological effects of the pandemic.

Furthermore, the age of children has an effect on parental resilience The resilience value of parents raising children aged 1113 years decreased and that of parents of adolescents aged 16-18 years increased. Presumably, in the adolescent independence process, self-effective conditions are experienced more frequently, which has a positive effect on the ability of parental resilience. Parents raising younger children reduce parental resilience as a combined effect of stress from home office and online education and conflicts of prepubertal developmental conflicts. The age of 
the child is decisive for parental resilience. During the COVID-19 period, parents raising children aged 11-13 years, and indirectly families, were at risk for stress.

Higher parental self-efficacy is associated with higher resilience of the child. A similar result was described by Turkish researchers in the spring phase of COVID-19 that maternal self-efficacy and pediatric resilience go hand in hand [14]. Parental self-efficacy in the way they handle their child-related responsibilities affects a child's ability to adapt [29]. A properly self-effective parent who employs a positive parenting and parenting strategy promotes his or her child's adaptation and maturation of emotion regulation [45].

\section{Conclusion}

In summary, the decrease in protective factors - resilience, wellbeing - in the pandemic period from spring to winter 2020 indicates the fatigue of the study participants with the increased perceived stress, which indirectly reduces the resilience. In the study sample, girls and parents (mothers) raising children of prepubertal age are most at risk. Protective factors and mobilizable resources capable of counteracting the negative effects of stress decreased significantly during the winter. One form of resource optimization can be to retain, reinforce, and consciously manage self-effective behavior. We recommend a creative search for independent selfeffective manifestations of parents and children. Assistance to the most vulnerable groups - girls and parents raising children with prepubertal children - has been a complex task, the development of which goes beyond the scope of this study. In the case of children, the lack of friends and school can be alleviated with creative solutions at individual, family and school levels, with the involvement of professionals where necessary.

\section{Limitations}

The gender distribution of the parental pattern shifted toward women. In further data collection, it would be important to try to balance the sample. During the second sampling, the sample also shifted in the education of the respondents towards the participant with higher education, so the presented results are valid in this population.

\section{Acknowledgments}

The study was carried out within the framework of the Research grant awarded to the Károli Gáspár Reformed University, Resilient Development-Positive Research Group, for which we thank. I would like to express my special thanks to Klára Soltész-Várhelyi for thinking together, for the illustrative figures presented and for her sharp-eyed critical thoughts.

\section{Bibliography}

1. Barton MC., et al. "Call for transparency of COVID-19 models". Science 368.6490 (2020): 482-483.

2. Bandura A. "Self-efficacy". The exercise of control. New York: Freeman (1994).

3. Bonanno G. "Loss, Trauma, and Human Resilience: Have We Underestimated the Human Capacity to Thrive After Extremely Aversive Events?" American Psychologist 59.1 (2004): 20-28.

4. Békés V. “A reziliencia-jelenség, avagy az ökologizálódó tudományok tanulságai egy ökologizált episztemológia számára”. In Forrai G. and Margitay T. (Szerk.) „Tudomány és történet” - Tanulmánykötet Fehér Márta tiszteletére (2002): 215-228.

5. Bonanno G A. "Loss, Trauma, and Human Resilience: Have We Underestimated the Human Capacity to Thrive After Extremely Aversive Events?" American Psychologist 59.1 (2004): 20-28.

6. Caplan G. "Principles of preventive psychiatry". Basic Books (1964).

7. Ciccetti D and Cohen D J. "Developmental Psychopathology". Volume One: Theory and Method; Volume Three: Risk, Disorder and Adaptation. Hoboken, NJ: John Wiley and Sons, Inc (2006).

8. Cohen S. "Perceived stress in a probability sample of the United States". In S. Spacapan and S. Oskamp (Eds.), The Claremont Symposium on Applied Social Psychology. The social psychology of health (1988): 31-67).

9. Connor K M and Davidson J R T. "Development of a new resilience scale: the Connor-Davidson Resilience Scale (CDRISC)". Depression and Anxiety 18.2 (2003): 76-82.

10. Dalton L., et al. "Protecting the psychological health of children through effective communication about COVID-19". The Lancet Child and Adolescent Health 4.5 (2020): 346-347.

11. Deater-Deckard K D., et al. "Parental Stress and Early Child Development". Adaptive and Maladaptive Outcomes. Cham: Springer International Publishing (2017). 
12. Deutsch és mtsai. "A jóllétet meghatározó tényezők vizsgálata egészségügyi szakdolgozók körében". Alkalmazott Pszichológia 15.2 (2015): 49-71.

13. Diagnostic and statistical Manual of Mental Desorders (DSM-V) (2013).

14. Dodur HMS and Kumas ÖA. "Knowledge and beliefs of classroom teachers about dyslexia: the case of teachers in Turkey". European Journal of Special Needs Education (2020).

15. Dozois D J A and Mental Health Research Canada. "Anxiety and depression in Canada during the COVID-19 pandemic: A national survey". Canadian Psychology/Psychologie canadienne. Advance online publication (2020).

16. Duan L., et al. "An investigation of mental health status of children and adolescent in china during the outbreak of COVID-19". Journal of Affective Disorders 275 (2020): 112-118.

17. Erikson E H. "Growth and crises of the "healthy personality". In M. J. E. Senn (Ed.), Symposium on the healthy personality (1950): 91-146.

18. Fehér Boróka. Hajléktalan emberek traumás élményei és azok feldolgozása narratív eszközökkel "Mit kellene tudni egy szociális munkásnak ahhoz, hogy a hajléktalanokkal dolgozni tudjon?" Doktori Disszertáció. ELTE Társadalomtudományi Kar Szociális munka - Szociálpolitika Doktori Program, Budapest (2010).

19. Fields L and Prinz R J. "Coping and adjustment during childhood and adolescence". Clinical Psychology Review 17 (1997): 937-976.

20. Fiorillo A and Gorwood P. "The consequences of the COVID-19 pandemic on mental health and implications for clinical practice". Cambridge University Press. 01 April (2020).

21. Hajdusa M. “A krízis lélektana”. ELTE Eötvös Kiadó, Budapest (2008).

22. Hampel P., et al. "Perceived stress, coping, and adjustment in adolescents". Journal of Adolescent Health 38 (2006): 409-415.

23. Holmes T and Rache R. "The social readjustment scale". Journal of Pychosomatic Research 11 (1967): 213-218.
24. Horesh D and Brown A D. "Traumatic stress in the age of COVID-19: A call to close critical gaps and adapt to new realities". Psychological Trauma: Theory, Research, Practice, and Policy 12.4 (2020): 331-335.

25. Horwitz A G., et al. "Specific coping behaviors in relation to adolescent depression and suicidal ideation". Journal of Adolescence 34 (2011) 1077-1085.

26. Jacobson G F. "Crisis-oriented therapy". Psychiatric of North America 2 (1979): 39-54.

27. Járai R. "A Connor-Davidson reziliencai kérdőív 10 itemes változatának jellemzői”. Alkalmazott Pszichológia 15.1 (2015): 129-136.

28. Jiao WJ. "Behavioral and Emotional Disorders in Children during the COVID- 19 Epidemic". The Journal of Pediatrics (2020): 264-266.

29. Jones T L and Prinz R J. "Potential roles of parental self-efficacy in parent and child adjustment: a review". Clinical Psychology Review 25 (2005): 341-363.

30. Killgore WDS., et al. "Three months of loneliness during the COVID-19 lockdown (2020)". Psychiatry Research 293 (2020).

31. Köteles F., et al. “A rövidített egészségszorongás-kérdőív (SHAI) magyar verziójának kérdőíves validáslása és pszichometriai értékelése". Mentálhigiéné és pszichoszomatika 12/3 (2011): 191-213.

32. Kövesdi A. "A reziliencia hatása a krónikus betegségekben". Gyermekgyógyászat 67.4 (2016): 225-230.

33. Kövesdi A., et al. "The Protective Role of Self-Efficacy for Resilience in the COVID-19 Period". Acta Scientific Neurology 3.11 (2020).

34. Kris E. "Psychoanalytic Explorations in Art". Int. Univ. Press, New York (1952).

35. Legerstee J S., et al. "Cognitive coping in anxiety-disordered adolescents". Journal of Adolescence 34 (2011): 319-326.

36. Maslow A H. "The instinctoid nature of basic needs". Journal of Personality 22 (1954): 326-347. 
37. Masten A S. “Ordinary magic. Resilience processes in development". American Psychologist 56 (2001): 227-23.

38. Mitchell Juliet. "Trauma, felismerés és a nyelv helye”. In: THALASSA 10 (1999): 2-3.

39. Olsson CA., et al. "Adolescent resilience: a concept analysis". Journal of Adolescence 26 (2003): 1-11.

40. Pikó B. Védőfaktoroknyomában. A káros szenvedélyek megelőzése és egészségfejlesztés serdülőkorban. L'Harmattan, Budapest (2010).

41. Salkovskis PM., et al. "The Health Anxiety Inventory: development and validation of scales for the measurement of health anxiety and hypochondriasis". Published online by Cambridge University Press (2002).

42. Selye J. "The physiology and pathology of exposure to stress. A treatise based on the concepts of the general-adaptation-syndrome and the diseases of adaptation". Acta, Montreal (1950).

43. Selye J. "Stressz distressz nélkül". Akadémia Kiadó. Budapest (1976): 79.

44. Shuquan C and George A. "Psychological Adjustment During the Global Outbreak of COVID-19:A Resilience Perspective". Bonanno, Columbia University, Psychological Trauma: Theory, Research, Practice, and Policy, American Psychological Association (2020).

45. Stack D M. “Parental effects on children's emotional development over time and across generations". Infants Young Child 23 (2010): 52-69.

46. Staudler A., et al. "Észlelt stressz kérdőív (PSS) magyar verziójának jellemzői”. Mentálhigéné és Pszichoszomatika 7.3 (2006): 203-216.

47. Turk T., et al. "Acute aortic insufficiency after blunt chest trauma: a case report". Journal of Cardiovascular Surgery (2007): 359-361.

48. Virágh Sz. "Trauma és történelem találkozása". Emlékezet, reprezentáció, rítus. BUKSZ (2011).

49. Werner E E and Smith R S. “Overcoming the odds: High risk children from birth to adulthood”. Cornell University Press (1992).
50. Woodgate RL. "Conceptual Understanding of Resilience in the Adolescent With Cancer: Part I". Journal of Pediatric Oncology Nursing 16 (1999): 35-43.

51. Zhou SJ., et al. "Prevalenced and socio-demographic correlates of psychological health problems in Chinese adolescents during the outbreak of COVID-19". European Child and Adolescent Psychiatry 29 (2020): 449-458.

\section{Assets from publication with us}

- Prompt Acknowledgement after receiving the article

- Thorough Double blinded peer review

- Rapid Publication

- Issue of Publication Certificate

- High visibility of your Published work

Website: www.actascientific.com/

Submit Article: www.actascientific.com/submission.php

Email us: editor@actascientific.com

Contact us: +919182824667 